\title{
Geographical and Policy Factors in Foreign Direct Investment Inflows to Africa
}

\author{
Oluremi Ogun ${ }^{1 *}$, Afees Salisu ${ }^{2}$, Afolabi Olowookere ${ }^{3}$, Fatai Ogunlana ${ }^{4}$ and Chris Ofonyelu ${ }^{5}$ \\ ${ }^{1}$ Professor of Economics, University of Ibadan, Nigeria \\ ${ }^{2}$ Senior Lecturer, International Training Institute, Nigeria
}

${ }^{3}$ Head of Research, Securities and Exchange Commission, Abuja, Nigeria

${ }^{4}$ Fatai Ogunlana, Senior Lecturer, Nigeria

${ }^{5}$ Lecturer Adekunle Ajasin University, Akungba-Akoko, Nigeria

*Corresponding author: Oluremi Ogun, Department of Economics, University of Ibadan, Ibadan, Nigeria

Submission: 眥 August 18, 2017; Published: 眥 May 30, 2018

\begin{abstract}
This paper analyzed the geographical and policy factors determining Foreign Direct Investment (FDI) inflows to four regions of Africa over the period 1980 to 2010. Based on the eclectic paradigm, a gravity model and threshold procedure, the paper found that geographical factors were the main attraction for FDI inflows to most regions of Africa. However, FDI would flow more to countries with lower level of inflationary tendencies. This pattern cuts across different models. Fiscal deficit ratio of less than $3.3 \%$ and inflation rate of less than $10 \%$ maximized the geographical advantage. Beyond these thresholds, FDI inflows to Africa appeared discouraged
\end{abstract}

Keywords: FDI; Capital inflow

JEL Code: F2

\section{Introduction}

The disappointing economic performance of African countries, coupled with increase in globalization activities in the world economy over the past two decades had caused a regime shift in favor of outward-looking development strategies [1]. Accordingly, many African countries had adopted restrictive trade policies and capital control measures as development strategies. The hitherto inward-looking strategies were observed to discourage trade, foreign direct investment (FDI) and growth in the region [2].

In order to counter the adverse effect of her population growth rate, Africa required increasing investment in order to assure sustained growth and development. Such desired increase in investment necessitated the mobilization of both domestic and international financial resources that could in part be met through increasing FDI inflows. FDI inflow constituted an important element of economic growth as well as a channel for diffusion of new ideas, technical innovation, accelerated integration, enterprise restructuring and capital account relief [3-5]. The inflow brought with it opportunity for technology transfer, enhanced competition and increased access to export abroad. Attracting FDI inflows therefore, constituted a preferred non-debt-creating method for financing external current account deficits in developing countries where such deficits were often large [6].

A number of factors positioned African countries as recipients of FDI inflows. The factors ranged from geographical [7] to policy [8-11] and political factors [12] among others. However, the first two sets of factors were pertinent for discussion because of their overriding relevance in driving FDI inflows among the newly emerging economies in recent time [6,13]. While inflows of FDI had been dominant among the natural resources-producing countries, renewed privatization programs and policies aimed at improving efficiency had contributed to maintaining large FDI inflows in a number of other countries [14].

This suggested that geographical and policy factors were central to major FDI inflows to the continent. Geographical factors referred to country-distinct features that acted as incentive to attracting FDI inflow while policy factors were the measures created to aid the internalization of the geographical advantage. In view of the fact that FDI inflows to Africa were market and resource-seeking, the distinctive pattern was bound to be driven by both geographical and policy factors [15]. 
This study investigated the determinants of FDI inflow into some selected African countries. It focused on the geographical and distinct policy advantages of the host countries. In addition, the study developed a common threshold for assessing differentiated or joint determination of FDI inflow by geographical and policy factors in Africa.

The remaining paper was organized as follows. Section II provided a background to the study by way of an overview of the FDI scenario in Africa. Section III dealt with a review of relevant literature while section IV presented the framework of measurement and empirical specification. Section $V$ discussed the results of the empirical investigations while section VI concluded.

\section{Stylized Facts on FDI Flows into Africa}

The available evidence on the trend of FDI inflow to Africa as well as the continent's share of the total global flows suggested a steady decline over the last two decades and recently, the flows had been unstable [16]. As a percentage of the total flows to developing countries, Africa's share fell from 10\% in 1980 to $7 \%$ during 2000 2004 , rose to $12 \%$ in 2009 and declined to $10 \%$ in 2010 [14,17]. Viewed in terms of global inflows, the continent's share fell from $2.3 \%$ in 1980 to about $1.5 \%$ during $2000-2004$, rose to $3.3 \%$ in 2010 but declined to $2.8 \%$ in 2011 [18]. These growth experiences were observed to be far behind that recorded by other developing economies.

Additionally, the flows within the continent had also been observed to be unequally distributed. For instance, over $70 \%$ of the inflows between 2003 and 2010 were concentrated in the top 10 host African countries that included South Africa, Egypt, Morocco, Algeria, Tunisia, Nigeria, Angola, Kenya, Libya and Ghana [19]. These countries were observed to share a number of common features such as large reserves of natural resources, active privatization programs and/or investment promotion activities and liberalized FDI policies among others.

Among the continent's sub regions, North Africa was observed to be the worst hit by decline in inflows. The region which had attracted sustained huge inflows experienced a new socio-political phenomenon that altered its economic environment. The Arab spring that began in late 2010 impacted negatively on investment inflows into Libya, Egypt and Tunisia as the political situation in the region became unstable. In the West African region, the two largest recipients, Nigeria and Ghana, posted contrasting fortunes: inflows increased significantly in Ghana as a result of discovery of oil, but this was not enough to compensate for the large fall in Nigeria following investment uncertainties that accompanied the proposed introduction of a new Petroleum Industry Bill perceived as unfavourable by multinational operators. The rise in Niger-Delta crisis also worsened the situation. The commencement of major oil exploration in Ghana had sparkled quick interest from many multinational firms seeking alternative sub-regional source of oil to Nigeria [14].

The trends of the inflows into other regions in Africa were observed to be unstable and declining in aggregate terms in Table 1. The inflows appeared to follow natural resource endowment, large market availability, population size and favourable economic conditions [17]. These determining factors summed up as either geographically or policy linked. While geographical factors were relatively stable in most countries, policy factors were dynamic and constituted a veritable means of attracting new investments, and/or consolidating existing ones. Geographical factors such as resource endowment and land lockedness had been behind most of the FDI inflows into the primary sectors.

Table 1: Total FDI inflow to African regions between 2000-2010 (in Billions of US\$).

\begin{tabular}{|c|c|c|c|c|c|c|c|c|c|c|c|}
\hline Regions & $\mathbf{2 0 0 0}$ & $\mathbf{2 0 0 1}$ & $\mathbf{2 0 0 2}$ & $\mathbf{2 0 0 3}$ & $\mathbf{2 0 0 4}$ & $\mathbf{2 0 0 5}$ & $\mathbf{2 0 0 6}$ & $\mathbf{2 0 0 7}$ & $\mathbf{2 0 0 8}$ & $\mathbf{2 0 0 9}$ & $\mathbf{2 0 1 0}$ \\
\hline Central Africa & 1.2 & 2 & 2.4 & 3 & 3 & 3 & 3.2 & 5.5 & 4 & 8.5 & 8 \\
\hline South Africa & 2 & 10 & 7 & 7 & 7.6 & 14 & 11.8 & 19 & 28.5 & 20 & 15.3 \\
\hline West Africa & 1.9 & 20 & 3 & 3.5 & 3.6 & 8 & 16 & 10 & 10.5 & 9.2 & 11 \\
\hline East Africa & 0.9 & 0.5 & 0.6 & 1.5 & 1.8 & 1.5 & 2 & 3.5 & 3.5 & 2.8 & 3.7 \\
\hline North Africa & 4 & 5.5 & 4 & 5 & 6 & 12 & 23 & 25 & 24 & 18 & 17 \\
\hline Total & 10 & 38 & 17 & 20 & 22 & 38.5 & 56 & 63 & 70.5 & 58.5 & 55 \\
\hline
\end{tabular}

Source: United Nations Conference on Trade and Development (UNCTAD), 2011

In Africa, natural resources appeared to have constituted the main attraction for FDI inflows. UNCTAD [17] reported that the percentage of foreign investment flows to the primary sector of the continent had ranged between 55\% and $80 \%$ and with suggestive evidence that the trend would likely rise. The situation summarily pointed in the direction of a crucial role for policy.

Empirically, evidence to suggest the magnitude of impacts that geographical factors and policies had on FDI inflows had been limited. Available evidence was inconclusive on the thresholds within which each of the factors became dominating $[6,8,12,13,20]$
Zeng et al. [8] found that policies that had been successful in other regions might not in Africa. Selhausen [20] observed that institutions and geography promoted FDI to the non-sub-Saharan Africa (non-SSA) than to SSA. Geography was observed to play modest and indirect roles compared to policy-related institutional factors. In Asiedu [12], both geographical and policy variables were merged such that a threshold at which either of the factors became dominating was established. Asiedu \& Naudé [11,12] had concentrated on only the SSA countries, while Selhausen [20] included the non-SSA countries. These studies however failed 
to investigate the distinct impact of determining factors at subregional level.

In view of the arguments on the relevance of policy factors, a look at the average performance of key policy variables of many African countries revealed that policy outcomes did not fall within the optimal regions suggested by the literature in Table 2. Most countries experienced higher levels of inflation and fiscal deficit ratio (FD/GDP) than the recommended optimal. Using the two as key policy variables, there was evidence that the subsisting policy environment might not sustain adequate FDI inflows into the continent

Table 2: Trends of Inflation and Fiscal-deficit ratio in selected countries.

\begin{tabular}{|c|c|c|c|c|c|c|c|c|c|}
\hline$S / N$ & $\begin{array}{c}\text { Country } \\
\text { name }\end{array}$ & $\begin{array}{c}\text { Average } \\
\text { Inflation } \\
\text { rate (1980- } \\
1990)\end{array}$ & $\begin{array}{c}\text { Average } \\
\text { Inflation } \\
\text { rate (1991 } \\
-2000)\end{array}$ & $\begin{array}{c}\text { Average } \\
\text { Inflation } \\
\text { rate }(2001 \\
-2010)\end{array}$ & $\begin{array}{l}\text { Average } \\
\text { FD/GDP } \\
\text { (1980- } \\
\text { 1990) }\end{array}$ & $\begin{array}{l}\text { Average } \\
\text { FD/GDP } \\
\text { (1991- } \\
\text { 2000) }\end{array}$ & $\begin{array}{l}\text { Average } \\
\text { FD/GDP } \\
\text { (2001- } \\
2010)\end{array}$ & $\begin{array}{c}\text { Average } \\
\text { Inflation } \\
\text { rate (1980- } \\
\text { 2010) }\end{array}$ & $\begin{array}{c}\text { Average } \\
\text { FD/GDP } \\
(1980- \\
2010)\end{array}$ \\
\hline 1 & Burkina Faso & 4.512 & 4.63 & 2.98 & -1.62 & -3.93 & -4.18 & 4.06 & -3.24 \\
\hline 2 & Ghana & 47.26 & 26.34 & 16.95 & -1.92 & -1.33 & -2.128 & 30.73 & -1.79 \\
\hline 3 & Guinea-Bissau & 58.58 & 35.01 & 0.19 & -0.74 & -3.87 & -5.3 & 32.14 & -3.3 \\
\hline 4 & Mali & 5.56 & 3.89 & 2.78 & -5.72 & -5.17 & -7.01 & 4.12 & -5.97 \\
\hline 5 & Nigeria & 19.27 & 30.54 & 13.01 & -0.17 & -17.13 & -2.46 & 20.94 & -6.59 \\
\hline 6 & S/Leone & 67.31 & 34.74 & 9.58 & -0.04 & -31.65 & -4.58 & 37.21 & -12.09 \\
\hline 7 & Egypt & 17.87 & 9.02 & 7.98 & -1.76 & -0.79 & -1.53 & 11.62 & -1.36 \\
\hline 8 & Morocco & 7.43 & 4.06 & 1.82 & -3.37 & -22.88 & -1.11 & 4.44 & -6.16 \\
\hline 9 & Tunisia & 8.49 & 4.5 & 3.35 & -1.89 & -1.97 & -1.38 & 5.45 & -1.75 \\
\hline 10 & Algeria & 36.44 & 74.69 & 9.15 & -4.34 & 3.59 & -11.8 & 40.09 & -4.18 \\
\hline 11 & S/Africa & 14.63 & 9.00 & 6.02 & -0.49 & -2.08 & -3 & 9.88 & -1.86 \\
\hline 12 & Malawi & 16.57 & 32.30 & 12.76 & -5.67 & -4.8 & -3.94 & 20.54 & -4.8 \\
\hline 13 & Mauritius & 11.56 & 7.56 & 5.8 & -20.1 & -1.18 & -1.67 & 8.31 & -7.65 \\
\hline 14 & Zambia & 46.28 & 68.12 & 15.53 & -0.025 & -1.91 & -2.6 & 43.31 & -1.51 \\
\hline 15 & Madagascar & 17.96 & 17.03 & 10.29 & -7.49 & -4.92 & -3.52 & 15.09 & -5.31 \\
\hline 16 & Ethiopia & 5.2 & 7.54 & 11.07 & -1.94 & -3.27 & -3.82 & 7.94 & -3.01 \\
\hline 17 & Rwanda & 4.65 & 17.30 & 7.99 & -0.32 & -1.91 & -1.06 & 9.98 & -1.1 \\
\hline 18 & Gabon & 7.3 & 3.88 & 1.83 & 1.123 & 1.21 & 2.25 & 4.34 & 2.6 \\
\hline 19 & Burundi & 18.27 & 59.25 & 168.88 & 0.09 & -0.87 & -3.85 & 82.13 & -1.27 \\
\hline 20 & Kenya & 11.47 & 16.6 & 7.92 & -0.77 & -0.7 & -3.45 & 12 & -1.64 \\
\hline
\end{tabular}

Sources: Compiled and computed from the data sets of International Monetary Fund's International Financial Statistics and World Bank's World Development Index.

\section{Literature Review}

This section is organized under two major headings as follows.

\section{Theoretical issues}

Several theoretical explanations of FDI flows and their determinants existed in the literature but Dunning's eclectic paradigm [21-24], also known as the ownership, location and internalization (OLI) model, appeared dominant. The paradigm identified three conditions as determining the flow of FDI to any economy.

The first is the ownership advantage that referred to the competitive advantage a foreign firm had which enabled it to compete with host domestic firms. Foreign investment was attracted when the source firm owned some comparative advantage in production (technology) and other allied assets relative to that of the host country.
The location component explained that FDI became preferable in a host country than others if some non-transferable advantages (e.g. labour advantages, natural resources, trade barriers that restricted imports, gains in trade costs and strategic advantages through intangible assets) were present in the country. The location advantage might come from the presence of favourable economic conditions, such as large market size, differences in countries' natural endowments, government regulations and macroeconomic policies that promised potential future revenue for market-seeking FDI. Geographical factors like distance and natural resource endowment became important sources of attraction when the FDI source firm was raw material-seeking [25].

The internalization motivation was derived from the fact that market imperfections created additional transaction costs during export and licensing. Thus, a FDI source country might choose to internalize the imperfection costs by investing in the market where 
it could explore imperfections, including reduction of uncertainty and transaction costs rather than external licensing or contracting. The greater the net benefit of internalizing cross-border intermediate product markets, the more likely the firm would prefer to invest in the foreign country than licensing the right to do so. Based on internalization paradigm, trade and licensing barriers make export and licensing less attractive to FDI. The source firm could circumvent such market imperfections by engaging in direct investment in the host country as a strategic alternative to serving domestic market [26].

Government policy might affect the internalization proposition in many ways. Government policies constituted the main source of creating or reducing market imperfections. The influence on the macroeconomic environment through initiation of domestic policies was connected with the amount of market imperfection that would be created and this could affect FDI inflows directly or otherwise. For instance, government intervention in the exchange rate market might cause deviations in currency values from parity levels, thereby, leading FDI to flow into the countries with undervalued currencies [26]. Rapid increase in fiscal deficit could worsen the position of an ailing economy and cause FDI to flow out of the host country. Other government policies like capital controls [27], inflation and political rights index [28], trade barrier, tax policy and incentive [5] and labour relation policies such as minimum wage $[5,26]$ affected FDI inflows via their impact on the host country's cost of production.

The presence of suitable geographical factors created incentive to guarantee returns on new foreign investment. For instance, availability of a resource endowment could cause FDI inflows to be driven by location advantage. A country with large stock of cheap labour, large population (market-size), and proximity to other large markets stood a chance to attract FDI inflows than where these factors were lacking.

The traditional internalization theory had argued that government policies created market imperfections that could make foreign companies to substitute FDI for trade and licensing. However, Brewer [26] had shown that government policies did not create market imperfections in all the cases as some might actually be imperfection-reducing. Government policies influenced FDI by altering the relative attractiveness of the host country to foreign investors in a wide variety of ways [29]. While it was possible for market imperfections to make FDI less attractive than export and licensing, the outcome might be complicated as it was possible for a single policy to simultaneously increase and decrease FDI. This kind of scenario would be a result of the interplay between policy and geographical factors. The need would arise therefore to establish the threshold at which policy or geographical factors drive FDI. The literature had suggested acceptable fiscal deficit to GDP ratio and inflation rate of 3 percent and less than 2 percent respectively.

Irrespective of the predominance of either of the factors in attracting FDI, the impact of policy factors in all economies was not homogenous. While most African countries relied on tax holidays and import duty exemptions as key policy emphasis, the industrial countries employed investment allowances and/or accelerated depreciation to create incentive for foreign capital inflow [30]. Low tax burden had been known to attract FDI in developed economies than in Africa [31]. Since most policy factors were flexible, FDI inflows into African economies might be influenced more by geographical factors, in view of their dominant market seeking nature. The policy factors might be adjusted to complement the geographical factors. At the general level, a predictable policy environment that promoted macroeconomic stability, ensured the rule of law and proper enforcement of contracts or minimized distortions, supported competitiveness and encouraged private sector development would expectedly stimulate private-sector driven foreign investment [5].

With regards to studies on determinants of FDI among African countries, the consensus appeared to be that the size and relevance of geographical and policy factors had not been well documented in the literature $[12,32,33]$. In addition, studies examining the optimal rate of FDI for developing economies had been rare. Asiedu \& Fedderke $[12,34]$ identified a number of policy and non-policy factors as determining FDI in Africa. The non-policy factors largely reflected the geographical factors influencing FDI. Generally, studies suggested that policy factors did matter for FDI inflows but there was inconclusiveness on geographical factors [6,30,35-40]. Earlier studies had assumed that factors attracting FDI in individual host countries operated in a vacuum such that policy factors were passive. Nevertheless, government policies influence FDI by altering the relative attractiveness of the host country to foreign investors in a wide variety of ways [27].

\section{Empirical literature}

The impacts of policy and non-policy factors as drivers of FDI had been the focus of many studies recently $[6,12,30,34,41]$. Although results from the studies tended to differ across countries, majority of the studies had established the relevance of geographical and policy factors. Generally, openness, market size and export orientation had been found to be the significant country-distinct determinants of FDI [42]. A number of the relevant studies were reviewed below in sequence.

\section{Evidence on the impact of geographical factors}

There was wide evidence on the impact of geographical factors within the context of FDI inflow. Several studies [6,12,30,41] found that geographical factors such as market size, population and resource endowment had positive impact while distance had negative effect. As established in the literature, the larger the size of the host economy and the closer the geographical and cultural proximity to the main FDI source countries, the greater the cumulative FDI.

Where the results differed, a probable reason adduced was the market-seeking and/or resource-seeking type of FDI favoured by the source firm. While a number of African countries possessed 
attractive geographical factors, many countries on the continent had not in recent time been able to attract impressive FDI inflows. Even as a number of the countries were landlocked, they also fell into the category of low FDI countries. This suggested that a number of other complementary factors (perhaps, the operational policy in the host country) also mattered in determining FDI inflows.

While resource endowment and availability were considered critical to attracting FDI in many African countries through vertical FDI (VFDI) flows, there was a broad agreement that Horizontal (HFDI) was more prevalent [43]. However, both types of FDI inflows were observed to respond to geographical and policy factors of the host country. In addition, given huge endowment of resources in most African countries, creating appropriate policy environment would appear to be important in maximizing FDI inflow.

\section{Evidence on the impact of government policies}

The impact of government policy at influencing FDI inflows could be examined within three broad categories: trade, monetary and fiscal policies. The key target of trade policy was the exchange rate. Depreciation of host country's currency was an incentive to localizing an FDI firm. Monetary policy influenced a chain of macroeconomic variables in the economy in the course of generating output growth. The key indicator of fiscal stance was the size of the budget deficit. While Africa was saddled with great challenge to her infrastructural availability, fiscal deficit across the continent hovered around the upper threshold while gross national expenditure (as percentage of GDP) remained persistently high.

Government policies were represented variously in the literature by, tax and incentives [5,13], corruption and political instability [12], trade openness [44]. Each of these measures had been found to impact FDI. Essentially, corruption, tariffs and political instability were imperfection-creating (internalization paradigm), while tax incentive and trade openness was imperfection-reducing. The impact of liberalization (measured by the extent of trade openness) was to reduce all associated wedge in the free movement of trade across national boundaries. The index of foreign exchange and trade liberalization were observed to have significant positive effect on FDI in South-eastern European countries [6].

The tax burden on business, captured by the statutory corporate income tax rate, was observed to have a significant negative impact on FDI. However, when empirical studies attempted to estimate the impact of individual policies on FDI, the results were often ambiguous [6]. Since the impact of corporate tax and trade barriers were dependent on the extent of the openness of the economy, government policies aimed at liberalizing trade were expected to have positive impact on trade volume. High level inflation was expected to negatively affect FDI inflows. Dabla-Norris et al. [45] found a positive impact of a low inflation environment on FDI inflows. Recent studies had produced evidence that a low tax burden would attract FDI [31]. While the evidence on tax incentive was inconclusive, simple and transparent tax system tended to encourage FDI inflow into any economy [46].

\section{Sensitivity of the impacts of geographical and policy factors} to host countries

There were evidences that the inclusion of a geographical factor might render another policy factor irrelevant. The inclusion of corporate tax in addition to tariff revenue showed inconsistent result about the behavior of the two variables. While production technology was not homogenous across Africa, most studies had seemly ignored the associated heterogeneity that arose when policy actions were assumed to generate uniform impact across the countries. The impact of an increase in tax burden on a resource deficit country might differ from that of a richly endowed country.

The incentive for market size might keep net FDI inflow positive while stiffer policy actions were initiated. The effect of geographical factors on each of the African region varied. The choice of representative factor variables might also be a source of variability of the results. For instance, Demekas et al. [6] showed that population (geographical factor) and income tax (government policy) were important only in countries with high level of GDP per capita while cultural ties and tariff policy were important at the lower levels of GDP per capita. In attempting to establish the thresholds at which each of the factors dominated, Demekas et al. [6] used GDP as the benchmark at which the use of other variables were feasible.

\section{Framework of Measurement and Empirical Specification}

The eclectic paradigm $[21,22,47]$ recognized the roles of geographical factors and government policies at influencing FDI flows hence, it served as the framework for this study. The paradigm was anchored on gravity model (GM) that predicted that just as the gravitational attraction between any two objects was proportional to the product of their masses but diminishing with distance, the transaction between any two countries was other things being equal, proportional to the product of their GDPs and diminished with distance. The flow of people, ideas or commodities between two locations related positively to size and negatively to distance [48]. Following the works of Arbatli, Campos \& Singh [6,49,50], FDI was modelled as a dynamic, partial adjustment process that assumed that the equilibrium level of FDI (FDI*) depended on a set of geographical $(\mathrm{G})$ and policy $(\mathrm{P})$ factors, alongside unobserved fixed and time-varying factors, $\mu_{\mathrm{it}}$.

$$
\text { 1. } F D I^{*}{ }_{i t}=a+b G_{i t}+c P_{i t}+\mu_{i t}
$$

The difference between equilibrium FDI and previous year's FDI flows represented the change in FDI as given in equation (4) after transformation through equations (2) and (3).

$$
\begin{aligned}
& \text { 2. } F D I_{i t}-F D I_{i t-1}=(1-\rho) F D I_{*_{i t}}-F D I_{i t-1} \\
& \text { 3. } F D I_{i t}-F D I_{i t-1}=(1-\rho) F D I^{*}{ }_{i t}-F D I_{i t-1}-\rho F D I_{i t-1} \\
& \text { 4. } F D I_{i t}=\rho F D I_{t-1}+(1-\rho) F D I_{i t}^{*}
\end{aligned}
$$

With $\varphi_{\text {it }}$ as omitted right hand side variables, the reduced form of equation (4) to be estimated then became: 


$$
\text { 5. } F D I_{i t}=\theta_{0}=\theta_{1} F D I_{i t-1}+\theta_{2} G_{i t}+\theta_{3} P_{i t}+\varphi_{i t}
$$

FDI referred to the aggregate FDI inflow, and was measured as a percentage of GDP for each of the African countries between 1980 and 2010. Elements of the Geographical Factors (G) included market size, Resource Endowment (re), Distance and Land Lockedness (llcd). Policy factors (P) were represented by exchange rate classification, real interest rate, inflation, intermediation ratio and fiscal deficit-GDP ratio. Market size was measured as the log of PPP-adjusted Per Capita as lower case GDP (pcgdp) and the log of population (pop) of the host country; distance (dist) was measured as the weighted (log) distance between the capital of the source countries and each of the host countries.

Furthermore, infrastructure was measured by per capita electric power consumption in individual countries. Exchange rate (exr), capital account restriction (car), interest rate premium and fiscal deficit (as ratio of GDP) were proxies, reflecting the host country's trade, monetary, international payment and fiscal policies respectively. M2gdp represented the development in the financial sector. Rapid growth in financial intermediation was expected to boost investment inflows. Interest rate differential (intdiff) represented the difference between the domestic lending rates in host countries and the average rate in inflow countries. An increase in this rate implied a premium for the investor firms and attracted localization of new investment into the host country. Incorporating these variables into equation (5) therefore yielded equation (6).
6. $F D I_{i t}=\beta_{0}+\beta_{1} F D I_{i t-1}+\beta_{2} p c d g p_{i t}+\beta_{3} p_{\text {op }}+\beta_{4} r_{\text {it }}+\beta_{5}$ infras $+\beta_{6}$ infl $l_{i t}+$

$\beta_{7} l l c d_{i t}+\beta_{8}$ dist $_{i t}+\beta_{9} \operatorname{exr}_{i t}+\beta_{10}$ car $_{i t}+\beta_{11}$ fdgdp $_{i t}+\beta_{12}$ intdiff $_{i t}+\beta_{13} m 2 g d p_{i t}+\varepsilon_{i t}$

Where, $\varepsilon_{\mathrm{it}}$ was error term equalled to the sum of $\mu_{\mathrm{it}}$ and $\varphi_{\mathrm{it}}$

Due to data unavailability, the effective model estimated was equation (7)

$$
\text { 7. } F D I_{i t}=\beta_{0}+\beta_{1} F D I_{i t-1}+\beta_{2} p c g d p_{i t-1}+\beta_{3} \text { infl } l_{i t}+\beta_{4} l l c k d_{i t}+\beta_{5} \text { dist }_{i t}+. \quad \text { exr }
$$$$
\beta_{6} \text { exr }{ }_{i t}+\beta_{7} f d g d p_{i t}+\beta_{8} \text { intdiff }_{i t}+\beta_{9} m 2 g d p_{i t}+\varepsilon_{i t}
$$

Population was excluded from the final equation because its impact was subsumed in the per capita income measurement. Similarly, real interest rate was dropped because of the presence of interest rate differential and inflation. In the estimation, considerations were given to some properties of equation (7). For instance, it was expected that there would be a correlation between the lagged FDI and the residuals and also there were more crosssectional units than the years $[6,13]$.

\section{Results and Discussion}

We started with the cross sectional country regressions, comprising the FDI flows between African countries and their key trading partners. The dependent variable was GDP weighted net FDI inflows between the source countries and 20 African countries averaged over the period 1980-2010. The size of the PPP-adjusted per capita GDP, distance between the host and their sources' capital and land lockedness represented the geographical variables.

\begin{tabular}{|c|c|c|c|c|c|}
\hline Variable & $\begin{array}{c}\text { (1) } \\
\text { Coefficient }\end{array}$ & $\begin{array}{c}\text { (2) } \\
\text { Coefficient }\end{array}$ & $\begin{array}{c}\text { (3) } \\
\text { Coefficient }\end{array}$ & $\begin{array}{c}\text { (4) } \\
\text { Coefficient }\end{array}$ & $\begin{array}{c}\text { (5) } \\
\text { Coefficient }\end{array}$ \\
\hline pcgdp & $\begin{array}{c}48.3979 * * * \\
(8.39)\end{array}$ & $\begin{array}{l}0.7196 \\
(16.05)\end{array}$ & $\begin{array}{c}60.4806^{* * *} \\
(16.504)\end{array}$ & $\begin{array}{c}113.043 \\
(27.647)^{* * *}\end{array}$ & $\begin{array}{l}18.3186 \\
(11.272)\end{array}$ \\
\hline m2gdp & $\begin{array}{l}3.8288 \\
(7.29)\end{array}$ & $\begin{array}{l}34.5413 \\
(23.85)\end{array}$ & $\begin{array}{l}18.25^{*} \\
(10.07)\end{array}$ & $\begin{array}{c}121.33 \\
(36.11)^{* * *}\end{array}$ & $\begin{array}{c}25.7062^{* * *} \\
(5.2276)\end{array}$ \\
\hline dist & $\begin{array}{l}1.791 \\
(1.28)\end{array}$ & (dropped) & (dropped) & $\begin{array}{c}0.184 \\
(3.0196)\end{array}$ & (dropped) \\
\hline exr & $\begin{array}{c}0.0096^{* * *} \\
(0.0)\end{array}$ & $\begin{array}{c}0.1542^{* * *} \\
(0.0016)\end{array}$ & $\begin{array}{c}0.0016 \\
(0.0022)\end{array}$ & $\begin{array}{c}0.9762^{* * *} \\
(0.3349)\end{array}$ & $\begin{array}{c}0.0015 \\
(0.0058)\end{array}$ \\
\hline fisdft & $\begin{array}{l}0.0000 \\
(0.00)\end{array}$ & $\begin{array}{l}0.0000 \\
(0.0000)\end{array}$ & $\begin{array}{c}0.0000 \\
(0.0000)\end{array}$ & $\begin{array}{c}0.0000 \\
(0.0000)\end{array}$ & $\begin{array}{c}0.0000 \\
(0.0000)\end{array}$ \\
\hline infl & $\begin{array}{l}-0.3753 \\
(0.034)\end{array}$ & $\begin{array}{l}-0.0729 \\
(0.0842)\end{array}$ & $\begin{array}{c}-0.0930^{*} \\
(0.056)\end{array}$ & $\begin{array}{l}0.3551 * \\
(0.1837)\end{array}$ & $\begin{array}{c}0.011 \\
(0.0491)\end{array}$ \\
\hline intdiff & $\begin{array}{l}0.0351 \\
(0.13)\end{array}$ & $\begin{array}{l}0.206 \\
(0.23)\end{array}$ & $\begin{array}{c}0.1416 \\
(0.1526)\end{array}$ & $\begin{array}{c}3.6934^{* * *} \\
(0.989)\end{array}$ & $\begin{array}{c}0.0692 \\
(0.1845)\end{array}$ \\
\hline cons & $\begin{array}{c}-441.492 \\
(74.17)\end{array}$ & $\begin{array}{l}-53.425 \\
(126.61)\end{array}$ & $\begin{array}{c}-555.95 \\
(142.861)\end{array}$ & $\begin{array}{l}-1285.18 \\
(248.814)\end{array}$ & $\begin{array}{l}-131.694 \\
(102.895)\end{array}$ \\
\hline No of Observation & 600 & 150 & 180 & 120 & 150 \\
\hline No of Countries & 20 & 5 & 6 & 4 & 5 \\
\hline
\end{tabular}

Table 3: Fixed Effect Panel Regressions across the African regions. 


\begin{tabular}{|c|c|c|c|c|c|}
\hline No of Instruments & 426 & 172 & 196 & 126 & 172 \\
\hline Observ per Group & 30 & 30 & 30 & 30 & 30 \\
\hline Prob > F & 0 & 0.0026 & 0 & 0.0002 & 0.001 \\
\hline
\end{tabular}

Note: (i) $* * *=1 \%$ significance; $* *=5 \%$ significance; $*=10 \%$ significance.

(ii) Figures in bracket were standard errors.

Source: computed.

\section{Host country characteristics as FDI determinants}

The result in [Table 3] referred to the fixed effects estimates of the panel regression of all the representative African countries. Based on the Hausman tests, fixed effect was accepted at $5 \%$. Land lockedness was excluded because of collinearity problem. The effects of the determining variables were examined first as a group, and subsequently as separate regions. This was intended to solve the likely endogeneity problems that might result from pooling data since FDI determining factors might vary across regions. In addition, geographical factors were observed not to be uniformly distributed across the countries.

Columns (1) to (5) contained the results for all the aggregate regressions, and all regions. Each column represented the determinants in each of the regions. Column 1 showed that both geography (pcgdp) and policy (exr) significantly attracted FDI inflow. Increase in market size (pcgdp), intermediation ratio (m2gdp) and distance (dist) were FDI enhancing. In addition, exchange rate depreciation, tolerable growth of fiscal deficit and increase in interest rate yield promoted investment inflow to the African region. Across the regions, the results showed market size (pcgdp), intermediation ratio (m2gdp), inflation rate (infl) and exchange rate (exr) to be key determining variables. Generally, increases in market size, financial sector development and exchange rate depreciation were the key factors attracting FDI inflows into the continent.

Even as the impact of inflation rate was not generally significant across the various regions, the average level of inflation was observed to be generally higher among the South and West African countries. Increase in inflation rate in the North and East African countries were observed to correlate positively with FDI inflow, but inversely for pooled South and West Africa. While the net returns on capital differed among the regions, increase in returns in South and West African regions might attract FDI inflow into the regions.
A reduction in fiscal deficits of North and East African countries was observed to be FDI enhancing but not so for the South and West African countries.

Except for the East African countries, increase in financial sector development attracted further increase in FDI flow among the other regions. The quest to diversify and capture long distance markets appeared to be a motive behind the FDI inflows to the regions. The major African recipients of FDI such as Morocco, Nigeria, Angola, Algeria and recently Ghana were countries rich in oil and mineral deposits which were geographical factors.

\section{Threshold Effects Estimation}

A number of techniques could be used to split the samples into groups for the purpose of threshold estimation. This paper adopted a modified version of Demekas et al. [6]. Since geographical factors were non-dynamic, we varied the magnitude of policy variables with respect to the size of net FDI inflow into the host country. Using inflation rate and fiscal deficit percentage of GDP as the key policy variables, the countries were first classified into two: first, as high and low inflation countries and subsequently as high inflationdeficit and low inflation-deficit countries.

Countries were selected into each of the categories based on the magnitude of the policy values. Countries whose inflation rate approximated double digits were classified as experiencing higher inflation but low otherwise. The literature had suggested a low level of inflation, basically single digit [51]. However, based on enormous growth deficits experienced in many less developed countries, optimal inflation rate that would be FDI inducing became pegged at $10 \%$.In view of the developing state of the African countries, we explored the implication of fixing policy variables around these benchmark rates. Based on these criteria, 13 countries were classified as high inflation countries with 7 contrasting. Six countries were observed to be both inflationary and deficit plagued. The foregoing classification produced the following regressions.

Table 4: Threshold Effects Estimation for Aggregate FDI Net inflow, 1980-2010.

\begin{tabular}{|c|c|c|c|c|}
\hline \multirow{2}{*}{ Variable } & $\begin{array}{c}\text { Coefficient } \\
\text { Inflation } \geq \mathbf{1 0} \% \\
\text { (Dynamic Pane) }\end{array}$ & $\begin{array}{c}\text { Coefficient } \\
\text { Inflation } \geq \mathbf{1 0} \% \\
\text { (Fixed Effects) }\end{array}$ & $\begin{array}{c}\text { Coefficient } \\
\text { Inflation } \geq \mathbf{1 0} \% \\
\text { (Dynamic Panel) }\end{array}$ & $\begin{array}{c}\text { Coefficient } \\
\text { Inflation } \geq \mathbf{1 0} \% \\
\text { (Random Effects) }\end{array}$ \\
\hline \multirow{2}{*}{ fdi (lag) } & $\begin{array}{c}\text { (Ro35** } \\
(0.035)\end{array}$ & 0.3545 & \\
\hline pcgdp & $35.5153^{* * *}$ & $79.2238^{* * *}$ & 8.33 & -0.2112 \\
$(11.10)$ & $(13.99)$ & $(13.47)$ & $(5.65)$ \\
\hline
\end{tabular}




\begin{tabular}{|c|c|c|c|c|}
\hline dist & $\begin{array}{l}0.0883 \\
(1.51)\end{array}$ & $\begin{array}{c}2.0066 \\
(1.4909)\end{array}$ & $\begin{array}{l}-3.80 \mathrm{e}+07^{*} \\
(21300000)\end{array}$ & $\begin{array}{c}-3.82 \mathrm{e}+07^{* * *} \\
(0.51869)\end{array}$ \\
\hline exr & $\begin{array}{c}0.0028 \\
(0.0010)\end{array}$ & $\begin{array}{c}0.0090^{* * *} \\
(0.0014)\end{array}$ & $\begin{array}{l}-0.0038 \\
(0.0111)\end{array}$ & $\begin{array}{c}-0.0188^{* *} \\
(0.0058)\end{array}$ \\
\hline m2gdp & $\begin{array}{c}-4.0582 \\
(9.0)\end{array}$ & $\begin{array}{c}17.0263 \\
(11.2884)\end{array}$ & $\begin{array}{c}0.5742 \\
(8.68)\end{array}$ & $\begin{array}{c}4.495 \\
(4.468)\end{array}$ \\
\hline infl & $\begin{array}{l}0.0115 \\
(0.028)\end{array}$ & $\begin{array}{c}0.0252 \\
(0.0394)\end{array}$ & $\begin{array}{l}0.0129 \\
(0.15)\end{array}$ & $\begin{array}{l}-0.0626 \\
(0.145)\end{array}$ \\
\hline intdiff & $\begin{array}{l}-0.1286 \\
(0.112) \\
\end{array}$ & $\begin{array}{l}0.0391 \\
(0.154) \\
\end{array}$ & $\begin{array}{l}-0.0965 \\
(0.368) \\
\end{array}$ & $\begin{array}{l}0.3559 \\
(0.296) \\
\end{array}$ \\
\hline fdgdp & $\begin{array}{c}0.0059 \\
(-0.015)\end{array}$ & $\begin{array}{c}0.0087 \\
(0.0245)\end{array}$ & $\begin{array}{l}-0.0018 \\
(0.0072)\end{array}$ & $\begin{array}{l}-0.0052 \\
(0.0067)\end{array}$ \\
\hline cons & $\begin{array}{l}-314.936 \\
(98.7626)\end{array}$ & $\begin{array}{l}-736.0196 \\
(124.6242)\end{array}$ & $\begin{array}{c}-54.13043 \\
(128.203)\end{array}$ & $\begin{array}{l}28.2865 \\
(50.615)\end{array}$ \\
\hline $\mathrm{R}^{2}$ & & 72.31 & & 77.66 \\
\hline No. of observation & 307 & 403 & 203 & 217 \\
\hline
\end{tabular}

Estimated Threshold Level: Inflation $=10 \%$.

Note: (i) $* * *=1 \%$ significance; $* *=5 \%$ significance; $*=10 \%$ significance.

(ii) Figures in bracket were standard errors.

(iii) Land lockedness was excluded due to collinearity issue.

Source: computed.

\section{Source: computed}

Table 4 showed results from two methods of regression: a dynamic and fixed or random (as suggested by the Hausman test). At higher level of inflation (above 10\%), geographical factors were observed to dominate the determination of FDI inflow to Africa irrespective of the methodology used. Distance and per capita GDP maintained a positive relationship with FDI inflow. At that level of inflation however, policy factors were observed to exert mixed influence on FDI inflow. Improvement in financial sector development that was positive at low inflation became inversely linked with FDI at higher levels of inflation. Financial sector development and interest rate premium were observed to be generally insignificant in the model. At higher levels of inflation, exchange rate became positively related to FDI inflows. The source firm became concerned about the value of the home country's currency vis-à-vis that of the host country, such that, depreciation of the domestic currency would become investment inducing.

Drawing on the suggested benchmarks for fiscal deficit in the literature, countries were classified as deficit when fiscal deficit ratio was greater than $3.3 \%$. This categorization led to the result in Table 5.

Table 5: Threshold Effects Estimation for Aggregate FDI Net inflow, 1980-2010.

\begin{tabular}{|c|c|c|}
\hline Variable & $\begin{array}{c}\text { Coefficient } \\
\text { Inflation } \geq 10 \% \text {; fdgdp }>3.3 \% \\
\text { (Dynamic Panel) }\end{array}$ & $\begin{array}{c}\text { Coefficient } \\
\text { Inflation } \geq 10 \% ; \\
\text { fdgdp }>3.3 \% \\
\text { (Random Effects) }\end{array}$ \\
\hline fdi (lag) & $\begin{array}{c}0.9228^{* * *} \\
(0.035)\end{array}$ & \\
\hline pcgdp & $\begin{array}{l}8.1997 \\
(5.092)\end{array}$ & $\begin{array}{c}13.1485^{* *} \\
(5.1582)\end{array}$ \\
\hline dist & $\begin{array}{c}0.1206 \\
(0.4266)\end{array}$ & $\begin{array}{l}1.5165^{*} \\
(0.8952)\end{array}$ \\
\hline exr & $\begin{array}{c}0.0019^{* * *} \\
(0.0006)\end{array}$ & $\begin{array}{c}0.0086^{* * *} \\
(0.0013)\end{array}$ \\
\hline
\end{tabular}




\begin{tabular}{|c|c|c|}
\hline m2gdp & $(-4.1923)$ & 3.3598 \\
$(8.8697)$ \\
\hline infl & $(3.737)$ & -0.0564 \\
& 0.02217 & $(0.0375)$ \\
\hline llcked & $(0.0163)$ & $7.5646^{* *}$ \\
\hline intdiff & $-3.2797)$ & 0.1812 \\
\hline fdgdp & -0.026 & -0.1246 \\
\hline cons & $(0.0552)$ & 0.01049 \\
\hline No. of & 0.0061 & $(0.01503)$ \\
\hline Observations & $(0.006)$ & -113.727 \\
\hline
\end{tabular}

Estimated Threshold Level: Inflation $=10 \%$.

Note: (i) ${ }^{* * *}=1 \%$ significance; $* *=5 \%$ significance; $*=10 \%$ significance.

(ii) Figures in bracket were standard errors.

Source: computed.

\section{Source: computed}

A fall out of Table 5 appeared to be that FDI was strongly attracted by geographical factors in high deficit and inflation plagued African countries. Except for landlockedness, all the geographical variables were significant and positively signed. As a country became inflationary and its finances marked by increasing deficit, exchange rate needed to depreciate to attract new foreign investments. In addition, the increase in inflation appeared to have crowded out the positive premium on the effect of money market interest rate differential. This probably explained the opposing signs and general insignificance of the variable under the dynamic panel and the random effect panel.

The source firms appeared more concerned with the geographical pull factors when policy factors were relatively unattractive or beyond acceptable thresholds. Market size (pcgdp) remained consistently an important determinant of FDI irrespective of the significance of policy factors. This appeared to partly underscore why FDI inflows were concentrated among the geographically endowed countries in Africa.

\section{Conclusions}

Geographical and policy factors had been found to be important determinants of the size and direction of FDI flows into African countries. Comparatively, it was found in the study that geographical factors were the main attraction for FDI inflows to most of the regions of Africa. However, FDI would flow more to countries with lower level of inflationary tendencies.

When the data were pooled, geographical factors, measured by market size and distance were very influential. This appeared to support the argument that most FDI inflows into Africa were resource-seeking. Further, in separate considerations, geographical factors had the most consistent impact in attracting FDI inflows into the regions but were insignificant when policy factors were found attractive. Fiscal deficit-income ratio and inflation rate were used as the key policy effectiveness variables. Fiscal deficit ratio of less than $3.3 \%$ and inflation rate of less than $10 \%$ were found to be FDI inducing, and maximized the exploration of the geographical advantage. Beyond these thresholds, FDI inflows into Africa appeared discouraged. Landlockedness of a country was not observed to be a major force in the FDI saga.

Governments could play important role in promoting FDI to Africa by implementing appropriate policies. The rate of inflation and proper alignment of domestic currency were of key importance to most FDI source firms. FDI inflows were reduced in inflationary (and high fiscal deficit) regime. Investors were keen on the purchasing value of the returns from their external investments. For those countries that were geographically disadvantaged, low inflationary and deficit environment appeared to be major attraction for new foreign investments.

\section{References}

1. Dupasquier C, PN Osakwe (2006) Foreign direct investment in Africa: Performance, challenges, and responsibilities. Journal of Asian Economics 17(2): 241-260.

2. Rodrik D (1998) Trade policy and economic performance in SubSaharan Africa. National Bureau of Economic Research Working p. 6562.

3. Holland D, N Pain (1998) The determinants and impact of foreign direct investment in the transition economies: A panel data analysis. Working Paper, National Institute of Economic and Social Research, London, United Kingdom. 
4. Garibaldi PN Mora, R Sahay, J Zettelmeyer (2002) What moves capital to transition economies? IMF Staff page number. 47.

5. Mateev M (2008) Determinants of foreign direct investment in Central and South Eastern Europe: New empirical tests. 8th Global Conference on Business \& Economics, $18-19^{\text {th }}$ October

6. Demekas DG, Horváth E Ribakova, Y Wu (2005) Foreign direct investment in Southeastern Europe: how (and how much) can policies help? IMF Working page number. 05/110.

7. UNCTAD (1999) Foreign direct investment in Africa: Performance and potential. United Nations: New York and Geneva.

8. Zeng LD, QS Tong, LWang Qian W (2002) On the determinants of foreign direct investment to developing countries: Is Africa different? World development 30(1):107-119.

9. Nicoletti GS Golub, D Hajkova (2003) The influence of policies on foreign direct investment. Experts' Meeting on Foreign Direct Investment in Developing Asia, November, 2003.

10. Borrmann A, M Busse, S Neuhaus (2006) Institutional quality and the gains from trade. Kyklos 59(3): 345-368

11. Naudé W, W Krugell (2007) Investigating geography and institutions as determinants of foreign direct investment in Africa using panel data". Applied Economics 39(10):1223-1233.

12. Asiedu E (2004) Foreign direct investment in Africa: The role of government policy, institutions and political instability. Retrieved on February, 25, 2012

13. Arbatli E (2011) Economic policies and FDI inflows to emerging market economies. IMF Working Paper, WP/11/192, International Monetary Fund, Washington DC.

14. UNCTAD (2011). Highlights of global FDI outlook. Retrieved on $24 / 9 / 2012$

15. Kinoshita Y, Campos NF (2002) The location determinant of foreign direct investment in transition economies. University of Michigan William Davidson Institute, US.

16. UNCTAD (2006) World development report-FDI from developing and transition economies: Implications for development. United Nations: New York and Geneva.

17. UNCTAD (2005) Economic development in Africa - Rethinking the role of foreign direct investments. United Nations: New York and Geneva.

18. World Investment Report (2011) Non-equity modes of international production and development.

19. UNCTAD (2010) Regional trends in FDI. Chapter II.

20. Selhausen FP (2009) On geography and institutions as determinants of foreign direct investment. A cross country comparative analysis of subSaharan African relative to developing countries

21. Dunning JH (1977) Trade, location of economic activity and the MNE: A search for an eclectic approach. In B. Ohlin, P. Hesselborn \& Wijkman PM (eds.), The international allocation of economic activity, pp. 395-418, Macmillan, London.

22. Dunning JH (1988) The eclectic paradigm of international production: and some possible extensions. Journal of International Business Studies 19(1): 1-31.

23. Dunning JH (1998) Location and the multinational enterprise: A neglected factor. Journal of International Business Studies 29(1): 45-66

24. Dunning JH (2004) The eclectic paradigm as an envelope for economic and business theories of MNE activity.
25. Buckley PJ, Clegg J, Wang C, R Adam (2002) FDI, regional differences and economic growth: panel data evidence from China. Transnational Corporations 11(1): 1-28.

26. Brewer TL (1993) Government policies, market imperfections and foreign direct investment. Journal of International Business Studies 24(1): 101-120.

27. Itagaki T (1989) The multinational enterprise under the threats of restriction on profit repatriation and exchange control. Journal of Development Economics 31(2): 369-377.

28. Bennett RD (2005) The determinants of FDI in Sub-Saharan Africa.

29. Globerman S, DM Shappiro (1990) The impact of government policies on foreign direct investment: The Canadian experience. Journal of International Business Studies 30(3): 513-532.

30. Morisset J and N Pirnia (2001) How tax policy and incentives affect foreign direct investment.

31. Hines JR (1999) Lessons from behavioral responses to international taxation. National Tax Journal 52(2): 305-322.

32. Asiedu E (2002) On the determinants of foreign direct investment to developing countries: Is Africa Different? World Development 30(1): 107-119.

33. Brunett A, G Kisunko, B Wider (1997) Institutional obstacles to doing business: Region-by-region results from a worldwide survey of the private sector. World Bank Policy Research page number. 1759.

34. Fedderke JW, AT Romm (2006) Growth impact and determinants of foreign direct investment into South Africa, 1956-2003.

35. Lipschitz L, TD Lane, AT Mourmouras (2002) Capital flows to transition economies: master or servant? IMF Working Paper No.02/11.

36. Demekas DG, B Horváth, Ribakova E, Wu Y (2007) Foreign direct investment in European transition economies - the role of policies. Journal of Comparative Economics 35(2): 369-386.

37. Witkowska J (2007) Foreign direct investment in the changing business environment of the European Union's new member states. Global Economy Journal 7(4): 2-30.

38. Dinda S (2009) Factors attracting FDI to Nigeria: An empirical investigation

39. Goodspeed T, Martinez Vazquez J, Zhang L (2010) Public policies and FDI location: Differences between developing and developed countries. Hunter College, Department of Economics, 695 Park Avenue, New York, USA.

40. Singhania M, A Gupta (2011) Determinants of foreign direct investment in India. Journal of International Trade Law and Policy 10(1): 64-82.

41. Reuber GH Crokelle, Emersen M, Gallias-Hamono G (1973) Private foreign investment in development. Development Centre of the OECD: Oxford.

42. Hein S (1992) Trade strategy and the dependency hypothesis: A comparison of policy, foreign investment and economic growth in Latin America and East Asia. Economic Development and Cultural Change 40(3): 495-521.

43. Navaretti GB, AJ Venables (2004) Multinational Firms in the World Economy, New Jersey: Princeton University Press, US.

44. Morisset J (1999) Foreign direct investment in Africa: Policies also matter. World Bank Policy Research Working page number. 2481.

45. Dabla-Norris E, Jiro H, Amina L, V Genevieve (2010) FDI flows to lowincome countries: Global drivers and growth implications. IMF Working Paper 10/132. 
46. Hassett KA, RG Hubbard (1997) Tax policy and investment. In: A Auerbach (Ed.), Fiscal policy: Lessons from economic research, Cambridge Mass, MIT Press, US, pp. 339-385.

47. Dunning, JH (1977) Trade, location of economic activity and the MNE: A search for an eclectic approach. In B. Ohlin, P. Hesselborn, \& P.M. Wijkman (eds.), The international allocation of economic activity, Macmillan, London, pp. 395-418.

48. Ghosh S, Yamarik S (2004) Are preferential trade agreements trade creating? An application of extreme bounds analysis. Journal of International Economics 63(2): 369-395.

49. Campos NF, Y Kinoshita (2003) Why does FDI go where It goes? New evidence from the transition economies. IMF Working Paper 03/228.

50. Singh H, KJun (1996) The determinants of foreign direct investment: new empirical evidence. Transnational Corporations 5: 67-106.

51. Coibion O, Gorodnichenko Y, Wieland JF (2010) The optimal inflation rate in New Keynesian models. NBER Working Paper No. 16093.

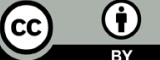

Creative Commons Attribution 4.0 International License

For possible submissions Click Here

\section{Submit Article}

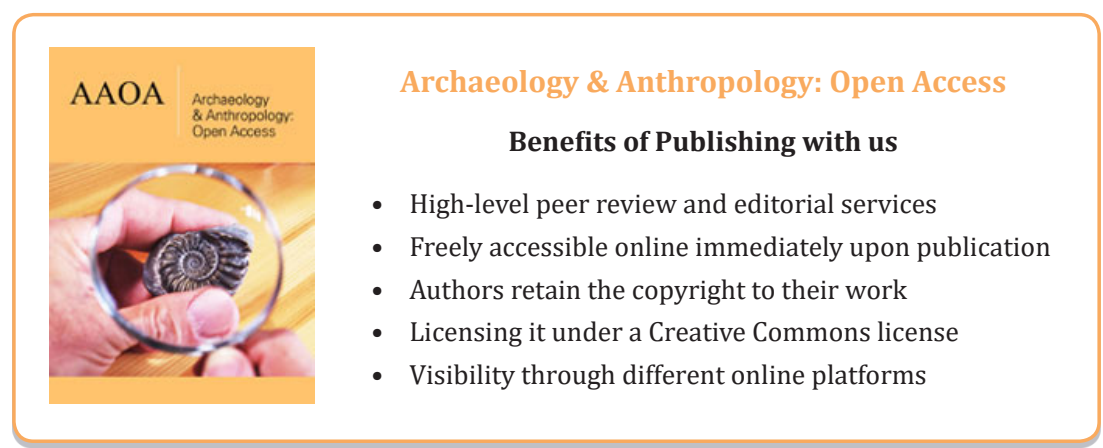

